University of Warwick institutional repository: http://go.warwick.ac.uk/wrap This paper is made available online in accordance with publisher policies. Please scroll down to view the document itself. Please refer to the repository record for this item and our policy information available from the repository home page for further information.

To see the final version of this paper please visit the publisher's website. Access to the published version may require a subscription.

Author(s): Shaun Breslin

Article Title: Understanding China's Regional Rise: Interpretations, Identities and Implications Year of publication: Forthcoming Link to published version: http://www.wiley.com/bw/journal.asp?ref=0020-5850 Publisher statement: ("The definitive version is available at www.blackwell-synergy.com") 


\section{Understanding China's Regional Rise: Interpretations, Identities and Implications}

\section{Shaun Breslin*}

\section{Level One Heading}

Level Two Heading

In an era when just about everything relating to change in China can be described as 'remarkable' and/or 'dramatic', it is perhaps not surprising that Chinese perceptions of, and policy towards, East Asia ${ }^{1}$ have undergone a radical transformation. Until the 1990s at least - as we shall see, until exactly when (and why) is debatable - Chinese policy was built on mistrust and suspicion, with most Asian states largely seen as agents of American foreign policy; a policy that was in no small part designed to prevent China's rise. Today, Chinese policy makers see considerable potential for the progression of Chinese objectives in the region, and China's economic and security interests are perceived as being best served by engagement and cooperation with the region - both through bilateral relations with individual regional states and through multilateral processes including the active promotion of formal regional institutions. Regional elites (particularly in Southeast Asia) now appear to have more in common with Beijing, be much more in tune with Chinese economic and security interests, and more tolerant/accepting of a growing Chinese regional role than at any other time since 1949.

\footnotetext{
* This paper was first presented at a workshop partly funded by the PSA Pacific Asia Specialist Group, and the University of Warwick Research Development Fund. Thanks to David Goodman, Peter Burnell, Kerry Brown, Greg Felker, Martin Gainsborough and Ian Taylor for comments on earlier versions, and to the anonymous reviewer for a number of very helpful comments.

${ }^{1}$ Defining the region is not easy. East Asia refers in this paper to the member states of ASEAN plus China, Japan and the Koreas. A broad definition of "China" would allow for the inclusion of Hong Kong, Macao and Taiwan.
} 
China's rise in Asia is clearly hugely significant. But it is important to retain a sense of balance in considering what has at times become a rather emotive issue - for example, in those analyses that are primarily concerned about the implications of China's rise for US power in the region (and sometimes beyond as well). At times, the search for new sources of a China challenge, and the desire to highlight the urgent need to respond, can give the impression that China has already usurped the US and is shaping the regional order as it pleases. This understanding tends to underplay the residual power of the US in East Asia, and can lead to the Association of Southeast Asian Nations (ASEAN) and individual Southeast Asian states being conceived as passive responders to Chinese initiatives, rather than possessing any sources of authority and influence themselves. ${ }^{2}$ At times, the casual observer could be forgiven for assuming that Japan had abandoned the region to Chinese influence and wholly eclipsed by China as the region's (sole) economic pole. Moreover, as China's regional power increases - or is perceived to increase - then the desire to find a balance has led to an increasing regional desire to see India play a greater role and perhaps change the very basic understanding of what is meant by 'region' in the Asian context.

In what follows, this paper first very briefly provides a survey of the literature on China's regional rise to show the conflicting understandings of broadly defined 'security' approaches on one hand, and 'political economy'/‘domestic politics' perspectives on the other. In particular, it highlights the different understandings of when policy changed, why it changed, and conflicting understandings of what is 'means' and what is 'ends'. And perhaps not surprisingly, even those who share a

\footnotetext{
${ }^{2}$ David Shambaugh, 'Return to the Middle Kingdom: China and Asia in the early Twenty-First Century' in D. Shambaugh, ed, Power Shift: China and Asia's New Dynamics (Berkeley: University of California Press, 2005), p. 24.
} 
basic approach sometimes disagree over the extent of Chinese power/influence/significance.

The second part of the paper then considers the main sources of China's growing influence in the region. Despite disagreement over the whys and whens and how fars, there is a consensus of sorts over how China has increased its influence in the region. To varying degrees, the focus is on a combination of diplomatic and economic drivers: the simple fact of the size and rapid growth of the Chinese economy and resulting trade flows, the diplomatic engagement of individual regional states and ASEAN as an organisation, the proactive promotion of formal institutionalised regional economic cooperation, and the increased significance of China as a source (rather than just a recipient) of foreign direct investment. ${ }^{3}$ Rather than simply repeat this consensus here, this paper instead focuses on a more contested potential source of Chinese power in the debates over the importance of ideas and the promotion of China's 'soft power' in Asia.

While the Chinese authorities are attempting to establish a new idea of what China is, what it stands for and how it acts, it seems that those who are most convinced about the rise of Chinese 'soft power' are either those who conflate ideational factors with harder (material) sources of power and influence, or those who are most eager to influence a change in Washington's foreign policy. In reality, it appears that where China has made most headway in attaining its objectives in the region and aligning others to Chinese interests, it is through working within existing frameworks and

\footnotetext{
${ }^{3}$ I have explored China's embrace of Asian regionalism in Shaun Breslin, "Comparative Theory, China, and the Future of East Asian Regionalism(s)', Review of International Studies (forthcoming).
} 
norms; and in one case through being more "liberal" than others in the promotion of regional free trade agreements.

Indeed, perhaps ironically, a key source of Chinese power is the assumption by others that it either has it - be that the external identification of soft power, or more tangible and "harder" sources of influence. Or maybe more correctly, it is the assumption that China will have this power and influence sometime soon. So alongside the reality of what China has done to date, and often based on well founded considerations, fears of what China might do and become in the future might play some role in creating the power that was feared in the first place.

\section{Changing Chinese Policy: When and Why?}

\section{Security Agendas}

Official Chinese statements constantly re-iterate the line that China does not and will never seek hegemony; neither in Asia nor elsewhere. Of course making bold statements about the desire to achieve hegemony would probably result in a hardening of positions against China. And from a security perspective, preventing a coalescence/alliance of forces that might threaten China's (security) interests is at the heart of China's changed regional policy. To be sure, the threat level is not the same as in the 1950s, 60s and early 70s, when Chinese policy makers were all but convinced that war with one or other of the superpowers (and perhaps even both) was inevitable. But if anybody had the ability to 'challenge Chinese territorial integrity' in the late 1990s it was the United States. ${ }^{4}$ And even if actual conflict was not likely, there was a real concern in Beijing that the regional order would obstruct the

\footnotetext{
${ }^{4}$ See Robert Ross, 'The Geography of the Peace: East Asia in the Twenty-First Century', International Security 23: 4, 1999, p. 93 and Michael Chambers, 'Framing the Problem: China's Threat Environment', Asia Policy 4 July 2007.
} 
attainment of national interests if left unchecked. Hence the need to build balancing relationships with regional states to (at the very least) neutralise their desire to contain China $;{ }^{5}$ to rebuild a triangular security environment in the region.

So if military security was the driver, when did policy change? A common response is that 1996 was the key year, and US support for Taiwan during the missile crisis the key event. ${ }^{6}$ Others date the change earlier in the decade, and point to the re-assertion of a 'good neighbour' policy (mulin zhengce 睦邻政策) ${ }^{7}$ based on the fear of potential international isolation after Tiananmen. ${ }^{8}$ While Suisheng Zhao accepts that this change was largely driven by great power concerns, he also points to the growing recognition that China's security considerations were best served by proactive engagement with Southeast Asian nations individually, and ASEAN multilaterally. ${ }^{9}$ For example, in the security realm, China and ASEAN (nations and the organisation) had a shared interest in dealing with marine piracy and transnational crime. A decade later, the SARS outbreak also illuminated the importance of information sharing and policy coordination to prevent new threats to human if not national security. Thus "old" and "new" security concerns came together to make regional engagement the logical strategic choice.

\footnotetext{
5 This is a common theme in the security literature on China's regional relations. For representative accounts see Michael Yahuda, 'Chinese dilemmas in thinking about regional security architecture', The Pacific Review 16: 2, 2003, pp: 189-206, pp: 61-66, Robert Sutter, 'Asia in the Balance: America and China's Peaceful Rise', Current History 103: 674, 2004, pp. 284-290, and Avery Goldstein, Rising to the Challenge: Chinas Grand Strategy and International Security (Stanford : Stanford University Press, 2005).

${ }^{6}$ For example, see Thomas Christensen, 'Fostering Stability or Creating a Monster? The Rise of China and U.S. Policy toward East Asia', International Security 31: 1, 2006, pp. 81-126.

7 Often referred to in China as a 'peripheral policy' - a policy towards China's peripheral areas or 周边政策 Zhoubian Zhengce.

${ }^{8}$ For example, David Shambaugh, 'China Engages Asia: Reshaping the Regional Order', International Security 29: 3, 2004-5, pp. 64-99.

9 Zhao Suisheng, Chinese Foreign Policy: Pragmatism and Strategic Behavior (Armonk: M.E. Sharpe, 2004).
} 
For those who see the security dilemma as the primary driver of regional policy, then all other policies are perceived as means of attaining that end. Thus expanding economic relations in the region is seen as a way of establishing trust with China's neighbours, and in the long run ensuring that the regions' economic future is dependent on what happens in China. ${ }^{10}$ For example, Zhang and Tang argue that China has decided that the best strategy is eventually to make China a locomotive for regional growth by serving as a market for regional states and a provider of investment and technology for the region. ${ }^{11}$

Robert Ross goes as far as to suggest that rather than just becoming dependent on China:

given the small size of the South Korea and Taiwan economies relative to the Chinese economy, their full integration in the larger Chinese economy is all but inevitable ${ }^{12}$

This power is also seen as being enhanced by the promotion of bilateral economic agreements that ensure access to the Chinese market to friendly states, and by using emerging multilateral forms as a way of supporting such 'commercial diplomacy' to compete with Japan and the US for support and even dominance in the region. ${ }^{13}$

\section{Domestic/Economic Drivers}

\footnotetext{
${ }^{10}$ For example, see Sutter, 'Asia in the Balance', Christensen, 'Fostering Stability', and Evan Medeiros, 'Strategic Hedging and the Future of Asia-Pacific Stability', Washington Quarterly 29: 1, 2005-6, pp. 145-167.

11 Zhang Yunling and Tang Shiping, 'China's Regional Strategy', in Shambaugh, Power Shift, p. 51.

12 Robert Ross, 'Balance of Power Politics and the Rise of China: Accommodation and Balancing in East Asia' in W. Keller and T. Rawski, eds, China's Rise and the Balance of Influence in Asia (Pittsburgh PA: Pittsburgh University Press, 2007), p.131.

13 For example, See Ellen Frost, 'China's Commercial Diplomacy in Asia: Promise or Threat?', in Keller and Rawski, China's Rise, pp. 95-117, Stephen Hoadley and Jian Yang, 'China's CrossRegional FTA Initiatives: Towards Comprehensive National Power', Pacific Affairs 80: 2, 2007, pp. 327-348, and Kuik Cheng-Chwee, 'Multilateralism in China's ASEAN Policy: Its Evolution, Characteristics, and Aspiration', Contemporary Southeast Asia 27: 1, 2005, pp. 102-22.
} 
But this idea that economics is the means and security the ends is not universally accepted. Political economists focus on the 1997 regional financial crisis as a crucial turning point, driving home the blunt reality that China's economic fortunes - and thus domestic political stability - were inextricably linked with what happens elsewhere. ${ }^{14}$ For a set of Chinese thinkers, realist conceptions of IR were found wanting in understanding the impact of globalisation, forcing a rethink of the relationship between political and economic dynamics, and the relationship between the domestic and the international. ${ }^{15}$ Perhaps most of all, it entailed a rethink of China's relations with the rest of the region and resulted in the understanding that an engagement policy was in China's own national (economics) self-interest. If such an engagement might help reduce the potential for regional elites to ally with the US, then all the better. But whereas security specialists see such great power politics as the cause of policy change, for political economists, it is seen more as a welcome biproduct of economically driven policy change.

For others, the source of this policy change lies much more squarely in the dynamics of domestic politics, and the CCP leadership's focus on keeping themselves in power despite myriad domestic challenges to stability - using diplomacy to serve domestic economic construction (waijiao fuwu yu guonei jingji jianshe

\footnotetext{
${ }^{14}$ For representative examples of this approach, see Joseph Fewsmith, 'China in 1998: Tacking to Stay the Course', Asian Survey 39: 1, 1999, pp. 99-113, Zha Daojiong, 'Chinese Considerations of "Economic Security", Journal of Chinese Political Science 5: 1, 1999, pp. 69-87 and Wang Zhengyi, 'Conceptualizing Economic Security and Governance: China Confronts Globalization', The Pacific Review 17: 4, 2004, pp. 523-4.

15 Examples include Fang Li (2000) ‘要重视研究世界经济全球化条件下国际政治经济关系的新特点 Yao Zhengshi Yanjiu Shijie Jingji Quanqiuhua taojian xia guoji zhengzhi jingji guanxi de xin tedian (Pay Attention to the New Characteristics of International Political Economy Relations in Researching World Economic Globalisation)', Dangdai Shijie (Contemporary World) 2, 2000, pp. 7-10 and Wang Yizhou, 全球政治和中国外交: 探寻新的视角与解释 Quanqiu Zhengzhi he Zhongguo Waijiao: Tanxun Xinde Shijiao yu Jieshi (Global Politics and Chinese Diplomacy: Exploring New Viewpoints and Explanations) (Beijing: World Knowledge Press, 2003).
} 
外交服务与国内经济建设). ${ }^{16}$ As perhaps most famously espoused by Susan Shirk, from this point of view foreign policy is seen as secondary to domestic concerns, and is driven by the insecurity of Chinese policy makers who are 'paranoid' that the CCP will suffer the same fate as communist parties further West. ${ }^{17}$ Domestic stability is partly maintained by engaging the region to guarantee the economic growth that is considered essential to maintaining domestic social stability, but also through ensuring that there are no external challenges - political or economic - so that the leadership can devote its attentions to pressing domestic concerns. Thus diplomatic initiates towards and in the region are partly driven by domestic economic concerns, but more squarely by the priority of regime survival rather than national security.

\section{Changing Images of China}

This quick survey of the literature reveals key differences in perceptions of the starting point of policy change, and also when this change began to occur. Not surprisingly, whilst there is a common focus on the need to change China's national image across these approaches, there are corresponding differences of opinion over why this is the case. For example, Shirk points to a position of weakness and fear of the consequences of an alliance to contain China which 'would wreak havoc on domestic stability in China'. ${ }^{18}$ In contrast, others point instead to the diminishing conception of China as a victim, and the internal transition to self-inferred great power status. ${ }^{19}$ It is a state that "no longer sees itself as a country facing imminent external danger or on the verge of internal implosion. Instead it sees itself as a country

\footnotetext{
16 Zhao, Chinese Foreign Policy, p. 259.

17 Susan Shirk, China: Fragile Superpower (New York: Oxford University Press, 2007), p.53.

18 Shirk, China, p. 105.

19 Evan Medeiros and Taylor Fravel, 'China's New Diplomacy', Foreign Affairs 82 : 6, 2003, pp. 2235.
} 
with resources for managing its grand transformation and a growing ability to shape its environment'. ${ }^{20}$

But whatever the starting point, analyses tend to converge on the recognition within the Chinese leadership of the need to change the way that others think of China, and how they expect it to behave. Chinese policy makers were acutely aware that their official rhetoric (and at times action) reinforced conceptions of China as a revisionist power and fuelled existing concerns about the consequence of China's rise. And notwithstanding disagreements about the nature of the cause of the change in policy, there is agreement on what it resulted in. 'Acutely conscious that its rapid rise leads other countries to view it as a threat', 'China's diplomats have worked hard since the 1990s to build its reputation as a good global citizen and regional neighbor' ${ }^{22}$ 'in an effort to remove the distrust and sense of insecurity among China's neighbours'. ${ }^{23}$

The task, then, was to construct an image of China as a 'responsible great power' fuzeren de daguo (负责任的大国 $)^{24}$ that does not threaten the interests of others, does not challenge the existing global order, and provides an opportunity for continued regional (and indeed global) economic prosperity. Or in the words of Robert Zoellick in 2005 , the way in which China is becoming 'a 'responsible stakeholder' in the existing international order. ${ }^{25}$ The attempt to change this image of China has partly been achieved through changing the practice of China's international relations -

\footnotetext{
${ }^{20}$ Zhang and Tang, 'China's Regional Strategy', p. 59.

21 Shirk, China, p. 11.

${ }^{22}$ Zhang and Tang, 'China's Regional Strategy', p. 52

${ }^{23}$ Bates Gill and Huang Yanzhong, 'Sources and Limits of Chinese "Soft Power", Survival 48: 2 , 2006, p. 24.

${ }^{24}$ Or sometimes just 负责任大国 Fuzeren Daguo.

${ }^{25}$ Robert Zoellick, 'Whither China: From Membership to Responsibility', Remarks to National Committee on U.S.-China Relations, New York, 21st September 2005. Available at http://www.cfr.org/publication/8916/whither_china.html accessed 13 May 2008.
} 
through joining the ASEAN Treaty of Amity and Co-operation in Southeast Asia in 2003, through the promotion of the China-ASEAN Free Trade Area, and so on.

China's 'responsible' behaviour in the Asian financial crisis is also considered to be an important signal of a change in Chinese policy. ${ }^{26}$

There has also been a deliberate attempt to create a discourse of China as responsible and benign though what is sometimes termed 'public diplomacy,27, 'international political marketing ${ }^{28}$ or the establishment of 'reputational capital' ${ }^{29}$ It is an organised project - what Kurlantzick amongst others has referred to as a 'charm offensive ${ }^{, 30}$ - to establish a preferred image of China. This is partly achieved through the promotion of a new cadre of diplomats - particularly within the region. Diplomats who know the language and culture of their host locations and who have been tasked with establishing this new image of China in their interactions with locals.

It is also achieved through the promotion of a new state ideology - the much vaunted idea of the 'Peaceful Rise' of China' (Heping Jueqi和平崛起) first proposed by Zheng Bijian at the Bo'ao Forum for Asia in 2003 as a direct counter-attack on the 'China Threat' theory. ${ }^{31}$ The specific term was dropped relatively quickly-partly because it generated as much attention on the 'rise' as it did on this rise being peaceful - and replaced by the conception of a 'Harmonious World' (Hexie Shijie 和谐世界) or

\footnotetext{
${ }^{26}$ Bronson Percival, The Dragon Looks South: China and Southeast Asia in the New Century (Westport: Praeger, 2007).

27 Wang Yiwei, 'Public Diplomacy and the Rise of Chinese Soft Power', The Annals of the American Academy of Political and Social Science 616: 1, 2008, pp. 257-273.

${ }^{28}$ Henry Sun, 'International political marketing: a case study of its application in China', Journal of Public Affairs 7: 4, 2007, pp. 331-340.

29 Joshua Ramo, Brand China (London: The Foreign Policy Centre, 2007), p. 27.

30 Joshua Kurlantzick, Charm Offensive: How China's Soft Power Is Transforming the World (New Haven: Yale University Press, 2007).

31 The Bo'ao Forum itself has become an agency of Chinese image and power promotion, acting as a means of promoting Chinese interests and ideas.
} 
sometimes peaceful world (Heping Shijie 和平世界) or peace and development (Heping yu Fazhan 和平与发展. $)^{32}$. But the basic idea of China as benign and a force for peace, stability and growth for all remains, and is a message that China's leaders rarely miss the chance to reaffirm.

Nor we should not overlook the extent to which the Chinese authorities have deliberately promoted the internationalisation of Chinese culture through festivals, 'China weeks' and so on across the world. Additionally, for Shambaugh educating others is an important means of transmitting values, establishing sympathy for Chinese aspirations and objectives, and increasing the power of attraction. ${ }^{33}$ Sheng and Saunders take a slightly different tack on focus on the importance of the promotion of the Chinese language. Whilst the expansion of language learning might be primarily driven by investment and trade agendas - the importance of doing business not just in China but with Chinese across the region - they argue that this as a spillover in increasing interest in wider forms of Chinese culture as well. ${ }^{34}$

\section{China as 'Alternative'}

And here we hit one of the conundrums of contemporary Chinese policy - the extent to which China is a status quo power, or whether it is an alternative to existing models and norms. The promotion of Chinese language learning overseas is organised by the Chinese Language Council International, more often known by the shortened version of its Chinese title, the Hanban (汉办). Part of the Hanban's duties is to promote

\footnotetext{
32 Robert Suettinger, The Rise and Descent of 'Peaceful Rise" China Leadership Monitor No. 12, 2004.

${ }^{33}$ David Shambaugh, 'Return to the Middle Kingdom'.

${ }^{34}$ Sheng Ding and Robert Saunders, 'Talking up China: An Analysis of China's Rising Cultural Power and Global Promotion of the Chinese Language', East Asia, an International Journal 23: 2, 2006, pp. 3-33.
} 
Confucius Institutes overseas - and the use of a historical figure as the personification of China's national image overseas is not accidental. While the contemporary political order might create more problems than attractions in the attainment of Chinese objectives, what China was remains something of an allure.

In assessing the Chinese language literature, Li Mingjiang notes that 'traditional Chinese culture .... is singled out as the most valuable source of Chinese soft power' ${ }^{35}$ The Chicago Council survey on soft power in Asia seems to bear this out, pointing to 'a deep respect for China's cultural heritage'. ${ }^{36}$ For Sheng Ding, the roots of the current emphasis on a new harmonious world order are found (or created) in China's past in an eclectic use of the combined philosophies of Mencius, Confucianism, Daoism, Sunzi and others. ${ }^{37}$

Not surprisingly, this reading of history is challenged. For example, Dirlik questions the pacific nature of domestic society in China's past:

Historically speaking, cliches about harmony and complementarity erase the whole history of labor conflict, women's struggles, and ethnic oppression in a Chinese society that went through one of the greatest and most painful revolutions in modern history ${ }^{38}$

\footnotetext{
35 Li Mingjiang, 'China Debates Soft Power', Chinese Journal of International Politics 2: 2, 2008, p. 292.

${ }^{36}$ Christopher Whitney and David Shambaugh, Soft Power in Asia: Results of a 2008 Multinational Survey of Public Opinion (Chicago: Chicago Council on Global Affairs, 2008), p. 5.

${ }^{37}$ Sheng Ding, The Dragon's Hidden Wings: How China Rises with its Soft Power (Lanham: Lexington, 2008), pp. 195-7.

38 Arif Dirlik, 'Confucius in the Borderlands: Global Capitalism and the Reinvention of Confucianism', Boundary 2, 22: 3, 1995, pp. 263-4.
} 
Cohen focuses on the external relations and the less that 'soft' use of Chinese power in the region, arguing that 'historically, a strong China has brutalized the weak'. 39

Rewriting history in a way that serves the present is not something that is unique to China - far from it, And notwithstanding issues about its provenance, Yoshihara and Holmes argue that this 'historical narrative' has become a major driver of Chinese soft power projection in recent years as a means of legitimating current practices by establishing links with (sometimes imagined) historical precedents. In their specific case study, this entails justifying China's current maritime policy by referring back to China's supposed peaceful naval explorations led by Zheng He in the early $15^{\text {th }}$ Century. ${ }^{40}$ For Wang and Lu the 'ancient' historical roots of current Chinese policy are reinforced by utilising 'a fragmented historical memory of the 19th century Opium War' to first establish common experiences of Western colonisation with other regional states, and then to reinforce the idea of Chinese power as 'different' from previous (Western) great powers. ${ }^{41}$

We seem, then, to be in a relatively new era of Chinese ideational persuasion through the creation - and 'creation' is an important word here - of an idea of an historical regional order that prospered when China was strong and in a leadership position. Chinese values are being promoted (and not just in the region) by referring back to idealised golden ages in a form of Occidentalism or 'reverse orientalism' in that they are depicted as the mirror image of all that the West (for which primarily read the US)

\footnotetext{
${ }^{39}$ Warren Cohen, 'China's Rise in Historical Perspective', The Journal of Strategic Studies 30: 4-5, 2007, pp. 683-704.

40 Toshi Yoshihara and James Holmes, 'China's Energy-Driven "Soft Power", Orbis 52: 1, 2008. pp. 123-137.

${ }^{41}$ Wang Hongying and Yeh-Chung Lu, 'The Conception of Soft Power and its Policy Implications: a Comparative Study of China and Taiwan', Journal of Contemporary China 17: 56, 2008, p. 470.
} 
stands for. Historical China's appeal to harmony, peace and virtue is seen as providing a cultural alternative to western materialism and individualism in those parts of the world that have suffered from western hegemony - be that colonial rule in the nineteenth and twentieth centuries, or the imposition of Western economic and political norms in more recent times. ${ }^{42}$

\section{A Caveat: State Projects and Intellectual Discourses}

Despite Dirlik's comments about the cliché of 'harmony', his work focuses on the importance of re-defining and re-inventing Confucianism (and not just in China) as a means of re-domesticating national capitalisms in response to the dominance of western global norms. And it is important to take this on board and distinguish between the creation of an idea of the past to suit official policy on one side, and intellectual endeavours to rethink China's place in the world on the other. The latter refers to an ongoing process of (re)thinking the nature of Chinese identity - an identity that is under threat from either 'globalisation' (however defined), or western cultural hegemony, or both.

It is difficult to pin down this process and pigeon hole it into a single school or approach. The term 'New Left' has become relatively widely used to refer to those who have highlighted the negative consequences of the transition from socialism and propose alternatives to embracing globalisation as a means of promoting development. ${ }^{43}$ But not all are concerned with economic paradigms and many

\footnotetext{
${ }^{42}$ For an overview of the evolution of Chinese norms, see Nicholas Thomas, 'China's Regional Governance: Developing Norms and Institutions' in N. Thomas, ed, Governance and Regionalism in Asia (London: Routledge/Curzon, 2009), pp. 116-145.

${ }^{43}$ See Gong Yang, ed, 思潮 - 中国新左派及其影响 Sichao - Zhongguo Xinzuopai ji qi Yingxiang (Ideological Trends - China's New Left and Their Influence) (Beijing: China Social Science Press, 2003).
} 
respects, the work of some of the most influential of critical thinkers attempts to go beyond a simple 'left-right' dichotomy and instead search for distinctive Chinese understandings of modernity. ${ }^{44}$ For Guo Jian, the main goal of these 'Chinese postists':

is to deconstruct Western knowledge of China and at the same time to explore various possibilities to reconstruct China's own cultural identity and national subjectivity $^{45}$

In doing so, they engage in processes that are similar to the state project of depicting China in a new way to an external audience - but in terms of method, epistemology and entomology, they are very different processes that should not be confused of combined into a single Chinese rethinking of history.

\section{International Norms and (Im)morality}

In terms of constructing a new international order, the Chinese alternative is based on four main pillars of foreign policy: a commitment to multilateralism underpinned by the central role of the UN as the guarantor of global security; a commitment to consultation and dialogue rather than force as a means of settling disputes; a commitment to global economic development with the developed world taking a greater share of the responsibility for promoting growth elsewhere; and a 'spirit of inclusiveness' for all societies and cultures to coexist as equal stakeholders in the global order. ${ }^{46}$

\footnotetext{
${ }^{44}$ Most of these scholars would define themselves as literature/cultural studies specialists and not political economists. Chen Xiaoming, Zhang Yiwu, Liu Kang, Wang Hui, Wang Ning, and Cui Zhiyuan are perhaps the best well known (in the West at least)

${ }^{45}$ Guo Jian, 'Politics of Othering and Postmodernisation of the Cultural Revolution', Postcolonial Studies 2: 2, 1999, p. 214.

${ }^{46}$ Sheng Ding, 'To Build A "Harmonious World”: China's Soft Power Wielding in the Global South', Journal of Chinese Political Science 13: 2, 2008, p. 197.
} 
In short, the message is that China values a democratic international order rather than the unipolar hegemony of the pax Americana. Moreover, China has utmost respect for state sovereignty rather than imposing values and policies on other countries. By forcefully reiterating that China does not have a normative agenda when it comes to dealing with other countries in start contrast to the US and the West, this 'antinormative' stance actually becomes a normative position itself. It is the promotion of a new norm of international relations (or actually an old norm - either old in terms of the recreation of China's history or old in the supposed basis of Westphalian sovereignty)!

Crucially for Gill, US foreign policy since September $11^{\text {th }}$ 'has opened new opportunities for China's emerging security diplomacy to succeed'. ${ }^{47}$ Add to this an inward turn in economic affairs ${ }^{48}$ and US action and inaction has created a spaceand not just in East Asia - that Chinese diplomacy has attempted to occupy. This diplomatic space is in no small part predicated on the declining moral authority and attraction of existing powers. As an Australian official interviewed by Lampton put it, it is 'negative soft power' - not being the US is at times enough to improve China's international image. $^{49}$

For Kang, this is particularly important in East Asia because it reinforces ideas about Asia as 'different'. The predominant cultural predisposition to hierarchy in the region means that Asian's like or perhaps even aspire to hierarchy. They are therefore

\footnotetext{
${ }^{47}$ Bates Gill, Rising Star: China's New Security Diplomacy (Washington DC: Brookings Institution Press, 2007), p. 2.

${ }^{48}$ T.J. Pempel, 'How Bush Bungled Asia: Militarism, Economic Indifference and Unilateralism have Weakened the United States Across Asia', The Pacific Review 21: 5, 2008, 547-581.

49 David Lampton, The Three Faces of Chinese Power: Might, Money and Minds (Berkeley: California University Press, 2008), p. 117.
} 
comfortable with the idea of a return to a hierarchical Sinocentric Asian order. If this is true, then the reaction in Asian states to the rise of China is based on some form of soft power; but the roots of this power lie not so much in the contemporary Chinese state, but in the creation of a historical 'Confucian' world order and a structure of international relations that permeates through into contemporary society. ${ }^{50}$

\section{The Attraction of the Chinese 'Model'}

The idea of China as alternative also spreads into the economic sphere and the attraction of China's economic system as a source of Chinese soft power. This 'model' has perhaps two main dimensions. The first is the managed process of reengagement with the global economy and the maintenance of relatively strong state control and/or national ownership of key economic sectors; in short, to globalise on your own terms rather than somebody else's. The second is that economic liberalisation has not been accompanied by political liberalisation and the move towards a competitive democratic system - a form of politically illiberal economic liberalism.

Of course there is a long tradition of such strong state led development that far predates the Chinese experience since 1978. Indeed, what China did was in some parts at least based on the success of the developing states in Asia. The similarity to the authoritarian economic growth that occurred in other parts of Asia in previous decades led Peerenboom to title his chapter on the Chinese developmental model, 'Déjà vu all over again'. ${ }^{51}$ In that the ideas of Friedrich List were the inspiration for

\footnotetext{
${ }^{50}$ David Kang, China Rising: Peace, Power and Order in East Asia (New York: Columbia University Press, 2007).

${ }_{51}$ Randall Peerenboom, China Modernizes: Threat to the West or Model for the Rest? (Oxford: Oxford University Press), pp. 26-81.
} 
the Bismarkian experience (that then in turn influenced Japanese developmentalism), and that his ideas were built on observations not just of Napoleonic Europe but also America continental integration and state-led development under Adams and Hamilton, perhaps the Chinese 'model' is in some ways has its origins in a previous 'Washington' model!

And it is in the challenge to the Washington Consensus that we perhaps find the roots of the idea of a Chinese model - but a challenge perceived from the outside rather than from within China itself. There had been considerable debate in China over the extent to which China's own experience formed part of a wider East Asian model, but the publication of Ramo's 'Beijing Consensus ${ }^{, 52}$ (known in Chinese as 北京共识 Beijing Gongshi) did much to promote the idea of the uniqueness of the Chinese development model'. ${ }^{53}$ At the heart of these understandings of the nature of the Chinese economic model 中国经济模式 zhongguo jingji moshi ${ }^{54}$ is the idea that it is something intrinsically 'Chinese' - something that has emerged out of the specific and peculiar circumstances that China found itself in, built on the specific and unique sets of resources available to the developmental elite.

And while there is clearly an element of national pride in the promotion of the success of China's developmental experience, the logical extension of this emphasis on specificity is that if there is a 'model', it is one that by definition is not transferable or not something that can be transplanted wholesale from the Chinese context to other

\footnotetext{
52 Joshua Ramo, The Beijing Consensus Notes on the New Physics of Chinese Power (London: Foreign Policy Centre, 2004).

${ }^{53}$ Young Nam Cho and Jong Ho Jeong, 'China's Soft Power: Discussions, Resources, and Prospects', Asian Survey 48: 3, 2008, p. 264.

${ }^{54}$ Or occasionally moxing 模型
} 
developing states. Rather the 'profound lesion' lesson that China provides for other developing states is 'start from national conditions, take your own road'

“从国情出发, 走自己的路 cong guoqing chufa, zou ziji de lu. ${ }^{55}$ The distinctiveness of the Chinese experience is summed up by the repetition of a key word in Pan Wei's definition:

[The] China model consists of four sub-systems, they are: a unique way of social organization, a unique way of developing its economy, a unique way of government, and a unique outlook on the world. (emphasis added) $)^{56}$

\section{Evaluating China's Regional 'Soft Power'}

Kurlantzick rather surprisingly sees the power of attraction as the source of burgeoning economic relations, arguing that the 'ASEAN-China free trade agreement, [is] possible only because of the appeal of China as an economic model' ${ }^{57}$ Most analysts would focus on other more pragmatic and materialist explanations of why the relationship emerged. But a key problem in trying to assess how successful this image promotion has been in the attainment of Chinese objectives is that it is simply all but impossible know what has motivated actors when they respond to China's regional rise. $^{58}$

Moreover, it is easy to infer what isn't really there. For example, the Chicago Council survey of Soft Power in Asia revealed a strong belief in the region that China's rise

\footnotetext{
55 Shen Li and Bai Qunying, ‘解读中国经济模式 Jiedu Zhongguo Jingji Moshi (Analysis of China’s Economic Model)' Guangming Ribao, 15 May 2006

${ }^{56}$ Pan Wei 'The Chinese Model of Development' Presentation at The Foreign Policy Centre, 11 October 2007, available at http://fpc.org.uk/fsblob/888.pdf p.2. Accessed 30 January 2009.

57 Joshua Kurlantzick, 'China's Charm: Implications of Chinese Soft Power', Carnegie Endowment Policy Brief No 47, June 2006, p.5.

58 Huang Yanzhong and Sheng Ding, 'Dragon's Underbelly: An analysis of China's Soft Power', East Asia: An International Journal 23: 4, 2006, p. 24.
} 
was 'inevitable', but recognised that acknowledging inevitability 'is not the same as liking it' ${ }^{59}$ It might be true that more and more students in the region are learning Chinese; that more and more policy makers and diplomats are considering Chinese interests before they make their final decisions; and more and more businessmen are also courting China. But this might in large part be because they think that China's rise to regional dominance is going to happen whatever they do or think, and so it's best to make the most of this inevitability.

\section{China's Rise or America's Decline?}

Another key problem is that it is all but impossible to disentangle the study of China's regional relations from conceptions of US (in)security. US based scholars have devoted considerable time and attention in recent years to the study of Chinese power in East Asia. The sub-discipline has been enriched by, amongst others, monographs by Sutter ${ }^{60}$ and Kang ${ }^{61}$, edited collections by Shambaugh ${ }^{62}$ and Keller and Rawski, ${ }^{63}$ and in a range of articles in International Security. ${ }^{64}$ There are also strong Asia dimensions to broader considerations of the implications of China's rise - Lampton's consideration of different dimensions of Chinese power, ${ }^{65}$ Shirk's understanding of

\footnotetext{
59 Whitney and Shambaugh, Soft Power in Asia, p. 5.

${ }_{60}^{60}$ Robert Sutter, China's Rise in Asia: Promises and Perils (Lanham: Rowman and Littlefield, 2005).

${ }^{61}$ Kang, China Rising.

${ }^{62}$ Shambaugh, Power Shift.

${ }^{63}$ Keller and Rawski, China's Rise.

${ }^{64}$ Aaron Friedberg 'Ripe for Rivalry: Prospects for Peace in a Mutlipolar Asia', International Security 18: 3, 1993-4, pp. 5-33; Denny Roy, 'Hegemon on the Horizon: China's Threat to East Asian Security', International Security 19: 1, 1994, pp. 149-168; Robert Ross, The Geography of the Peace: East Asia in the Twenty-First Century', International Security 23: 4, 1999, pp. 49-80; Alistair Johnston, 'Is China a Status Quo Power?', International Security 27: 4, 2003, pp. 5-56; David Kang, 'Getting Asia Wrong: The Need for New Analytical Frameworks', International Security 27: 4, 2003, pp. 57-85; Shambaugh, 'China Engages Asia', and Christensen, 'Fostering Stability. Thomas Berger, 'Set for Stability? Prospects for Cooperation and Conflict in East Asia', Review of International Studies 26: 3, pp. 408-428 wasn't published in the same journal but was influenced by Friedberg and forms part of the debate over the prospects for stability in the region.

${ }^{65}$ Lampton, The Three Faces of Chinese Power.
} 
the fragility of the Chinese regime, ${ }^{66}$ Goldstein's understanding of China's Grand Strategy, ${ }^{67}$ Gill's focus on security diplomacy ${ }^{68}$ and Johnston's forensic investigation of how China is being socialised into international norms through participation in global and regional regimes. ${ }^{69}$

It is not surprising that Asia figures so highly in these considerations of the implications of China's rise. It is in its own neighbourhood that China is most active, and has made the most progress in establishing itself as a major (if still not quite yet the primary) power. It is also the region in which the power of the US is perhaps most under threat. As a result, there are some who are concerned that negative perceptions of the US and/or a neglect of the region and/or US foreign policy initiatives in the Middle East have resulted in declining support for Washington. Moreover, the association of the US with the policies promoted in the region by the IMF in the wake of the Asian financial crisis are also seen as undermining support in the values and culture of the US (culture defined in political economy terms if not in the continued appeal of Disney, coke, Nike and Marlborough). So in many respects, interest in the rise of China's soft power should be seen alongside the concomitant concern about the loss of US soft power in particular, and challenges to US hegemony in general.

All of these studies of course $\underline{\text { about }}$ China, but they are also in many respects for the

US. They are designed at least in part to influence the way in which US policy makers think about and act towards China by first assessing the nature of this thing called China; then assessing the nature of the challenge that it poses to the US; and finally

\footnotetext{
66 Shirk, China.

${ }^{67}$ Goldstein, Rising to the Challenge.

${ }^{68}$ Gill, Rising Star.

${ }^{69}$ Alistair Johnston, Social States: China in International Institutions, 1980-2000 (Princeton and Oxford: Princeton University Press, 2008).
} 
assessing the efficacy of different responses in defending US national interests. To suggest that much of the literature on Chinese power is intended to influence a policy audience in Washington is not particularly heretical - most of these works are explicit in their intention and have chapters devoted to explaining what this means for the US and how the government should respond. Keller and Rawski perhaps speak for them all when they say that 'our investigation is structured to inform a US policy on Asia capable of responding to dynamic change' in light of an 'apparent US disengagement from Asia'- an 'unfortunate coincidence' of the decline of the US with China's new regional initiatives. ${ }^{70}$

This 'policy advocacy' dimension to analyses of Chinese power needs to be kept in mind when trying to evaluate the consequences of China's changed regional policy not so much when reading the studies referred to above, but in at least some of the warnings of an impending tip in the balance of power. And when the intention is to convince an audience, it is important to get the message across. So when it comes to talking about Chinese 'soft power', the broader the definition of what it actually is, then the greater the amount of power that China seems to have (and the more urgent the threat to the US). For example, despite his earlier comments about the attraction of the Chinese model, the rather 'hard' strategic use of economic relations as a means of achieving power politics objectives is at the heart of Kurlantzick's definition of the sources of Chinese soft power. ${ }^{71}$ Windybank also uses economic relations including politically inspired trade and aid and concludes that the challenge to the US is real and urgent - 'through a combination of trade, aid and skilful diplomacy, Beijing is laying the foundations for a new regional order with China as the natural leader and the

\footnotetext{
${ }^{70}$ William Keller and Thomas Rawski, 'Asia’s Shifting Strategic and Economic Landscape', in Keller and Rawski, China's Rise, pp. 4-5.

${ }^{71}$ Kurlantzick, Charm Offensive.
} 
United States as the outsider'. ${ }^{72}$ Or perhaps it is simply best summed up by the title of Mosher's 2001 book - Hegemon: China's Plan to Dominate Asia and the World. ${ }^{73}$

Moreover, while the focus on this paper is simply on Asia, this understanding is taken further and applied to challenge to US dominance across the world. The Washington Consensus model of development is under threat and Fukuyama's claim that 'liberal democracy remains the only coherent political aspiration, ${ }^{74}$ seems challenged by the aspiration of some (elites) at least to emulate China's model of politically illiberal strong state capitalism which:

could set scores of developing nations away from the path of liberal democracy, creating a community of countries that reject Western views of human rights and accepted standards of national governance ${ }^{75}$

\section{Norm Setter or Norm Taker?}

To be sure, this position is towards the extreme of interpretations and there are others that point in different directions. For example, Ellen Frost sees little that attracts pointing to the 'increasingly archaic' political system as something that repels rather than appeals. ${ }^{76}$ Surveys suggest that the appeal of the United States is still extremely strong (and stronger than China's) in the region, ${ }^{77}$ and in responding to Pempel's persuasive argument that the Bush administration 'bungled Asia', ${ }^{78}$ Michael Green

\footnotetext{
72 Susan Windybank, 'The China Syndrome', Policy 21: 2, 2008, p. 28.

73 Steven Mosher, Hegemon: China's Plan to Dominate Asia and the World (New York: Encounter Books, 2001).

${ }_{74}$ Francis Fukayama, The End of History and the Last Man (London: Penguin, p.xiii).

${ }^{75}$ Naazneen Barma and Ely Ratner, 'China's Illiberal Challenge', Democracy: A Journal of Ideas 2, 2006, p. 57. Cited in Chan Lai-Ha, Pak Lee and Gerald Chan, 'Rethinking Global Governance: a China Model in the Making?' Contemporary Politics 14: 1, 2008, 3-19.

${ }_{76}$ Frost, 'China's Commercial Diplomacy', p. 203.

77 Whitney and Shambaugh, Soft Power in Asia.

78 Pempel, 'How Bush Bungled Asia'.
} 
(who was part of that administration) found no evidence that Asian elites were abandoning Washington for Beijing:

rather than turning to an imagined 'Beijing consensus' on authoritarianism and non-interference in internal affairs, Asia's other major powers from India to Japan and Indonesia are emphasizing universal norms and their own democratic identity, even as they seek closer pan-Asian modes of cooperation. None of this is meant to minimize the significant ${ }^{79}$

Within China itself, various reviews of the debates on Soft Power find no consensus over whether external views and perceptions of China provide an asset or an obstacle for the attainment of national interests. But there is a consensus of sorts that anything that China is doing in soft power promotion has some way to go before the attraction of the US is eclipsed. ${ }^{80}$

Indeed, for Zhao, if China is to eventually defeat the US in terms of 'the soft power contest' this will not so much come from challenging existing liberal norms as through increasingly internalising them and implement 'liberal and democratic reform' ${ }^{81}$ And this position brings us back to the question of whether China is providing an alternative, or is instead conforming to existing norms. The apparent mismatch between China as responsible conformist power versus China as alternative can be reconciled by thinking in terms of different audiences for Chinese national image promotion. On a very basic level, the blunt distinction between the promotion of responsibility for an international audience and power projection for a domestic

\footnotetext{
79 Michael Green, 'The United States and Asia After Bush', The Pacific Review 21: 5, 2008, p. 584.

${ }^{80}$ See Li Mingjiang, 'China Debates Soft Power', Sheng Ding, The Dragon's Hidden Wings, Wang and Lu, 'The Conception of Soft Power', Huang Sheng. 'Dragon's Underbelly' and Young Nam Cho and Jong Ho Jeong, 'China's Soft Power'.

${ }^{81}$ Zhao Suisheng, 'Ambiguous Challenge', Chinese Security 4: 3, 2008, p. 10.
} 
nationalist constituency is a caricature of a more complicated position. But like most caricatures, it is an exaggeration that is built on at least some element of reality.

We can unpack this caricature by pointing to the diversity of domestic Chinese audiences, ideas and interests. Shen has identified a range of diverse voices and positions within the broadly defined 'nationalist' constituency itself (which makes it much harder for the Chinese government to respond to nationalist pressures than a blunt understanding of a single nationalist position would suggest). ${ }^{82}$ We can also unpack it by thinking of different external audiences. For example, as already noted, discourses of the appeal of China as alternative tend to focus on developing states in Latin America and most often Africa. Moreover, whilst the rhetoric of official China highlights the differences between Chinese actions and expectations compared to those of western states, the idea of China as alternative is at least as much inferred from without as promoted from within.

Despite concerns about the promotion of a Chinese alternative in Asia, the evidence seems to suggest that attitudes and opinions of China seem to improve as it increasingly transforms to meet existing global norms. Asia has become more enamoured with China as it has abandoned its old positions and regional leaders 'welcome China's penchant for making deals rather than fomenting revolution and applaud the recent flurry of regional and bilateral free trade agreements' ${ }^{83}$

The same seems to be true in the economic realm. Earlier, we noted that Zhang and Tang believe that the Chinese leadership is using trade and investment as a means of

\footnotetext{
${ }^{82}$ Simon Shen, Redefining Nationalism in Modern China: Sino-American Relations and the Emergence of Chinese Public Opinion in the 21st Century (Basingstoke: Palgrave, 2007).

${ }^{83}$ Keller and Rawski, 'Asia's Shifting Strategic and Economic Landscape', pp. 5-6.
} 
obtaining security objectives by establishing a Sinocentric regional economic order. But this attempt to place China at the centre of the region is more a consequence of conforming than of confronting, and results from the changing ideational basis of Chinese foreign policy and the increasing acceptance of 'neoliberalism's core belief that economic interdependence creates common interest and lessens the probability of conflict' ${ }^{84}$

It might be the case that China's turn to embrace the region has undermined the power of the US in Asia. But ironically, one of the great challenges to US power, it seems, is China accepting at least some global norms that successive US governments have tried to promote. So the China threat to the US in the region and elsewhere might not emerge form promoting an alternative model as the 'Beijing versus Washington Consensus' debate might suggest, but instead as Hu Xijin puts it by 'playing by the rules that Westerners themselves have formulated, the Chinese are beating them at their own game'. ${ }^{85}$ In the case of the ASEAN China Free Trade Area, it is not so much the acceptance, as the promotion, of liberal norms and by being more liberal than others by providing market access to agricultural producers that China's 'competitors' find it difficult to countenance. ${ }^{86}$ So China is thought to be competing by being economically more liberal than its liberal democratic rivals.

Debates over the growth of Chinese soft power are largely grounded in concern about the declining appeal of western liberal political and economic norms. Interventionist

\footnotetext{
${ }^{84}$ Zhang and Tang, 'China's Regional Strategy', p. 51

${ }^{85} \mathrm{Hu}$ Xijin, 'A Competitive Edge', Chinese Security 4: 3, 2008, p. 27.

${ }^{86}$ Yue Chia Siow, 'ASEAN-China Free Trade Area', Paper for presentation at the AEP Conference, Hong Kong, 12-13 April, available at http://www.hiebs.hku.hk/aep/Chia.pdf, accessed 29 March 2008. Though as Yue points out, this is possible because these sectors are less politically sensitive in China than in Japan.
} 
foreign policies combined with pressure to liberalise (including to liberalise economic sectors that remain relatively closed in many western states) both bilaterally and through western dominated international financial institutions have indeed result in distrust. In this context, then simply defining a contra-position is enough in many cases to win approval and to establish legitimacy and morality in international interactions. China does not so much need to promote an ideology as oppose the promotion of ideologies, and from this perspective, the attempt to talk to Washington and give a warning of the space that US policy is creating for China to possibly flourish is entirely understandable.

It also means that there is much that can be done in the US in particular to claw things back. Kishore Mahbubani has been one of the most vocal proponents of the decline of the West and in the words of the subtitle of his 2008 book, 'the irresistible shift of global power to the East' ${ }^{87}$ But he nevertheless acknowledges that at least some of the decline of the US in the eyes of others changed in November 2008 as 'America has once again become a beacon of hope. At least half of the anti-Americanism around the world has disappeared with Obama's election' ${ }^{88}$ To be sure, Mahbubani argues that it will be easy for Obama to disappoint, and for the goodwill to be simply dissipated. But we might suggest that at least some of the international ideational space that China has been able to move in with relative ease during the Bush years might have become somewhat squeezed.

\section{Economic Power, Soft Power and Crisis Management}

\footnotetext{
87 Kishore Mahbubani, The New Asian Hemisphere: The Irresistible Shift of Global Power to the East (New York: Public Affairs, 2008)

${ }^{88}$ Kishore Mahbubani, 'Look East Please', The Star $9^{\text {th }}$ November 2008.
} 
But while 2008 might have seen some of the appeal of the US return in the form of Obama's election, it was also a year in which the appeal and legitimacy of unregulated global neoliberalism was severely undermined. Even before the crisis, many Chinese exporters were facing difficulties as the removal of tax incentives and the rising Renminbi cut already very narrow profit margins. In the summer of 2008, China's top leaders visited those coastal provinces with the greatest concentration of export industries as workers were laid off in ever greater numbers and factories began to close. ${ }^{89}$ The collapse in consumer demand in Japan, the US and Europe served only to exacerbate existing problem resulting in a sharp decline in exports, the closure of thousands of small factories - particularly in Zhejiang Province and in the Pearl River Delta - and at least 20 million migrant workers losing their jobs. ${ }^{90}$

Of course it will be some time before the long term implications of the crisis for Chinese development become clear. The potential for labour disputes as factories close and declined rural incomes as remittances from migrant workers dry up is balanced by the government's ability to pump money into the economy to support both consumers and producers. The relatively shallow level of integration into the global economy through the dependence on imported components to produce exports (which accounted for around 58 per cent of all exports before the global crisis) also limits the impact of the decline in export markets on the economy as a whole. The significance of export growth for growth as a whole was and is clearly still hugely significant, and the loss of export markets has forced many producers into bankruptcy

\footnotetext{
${ }^{89} \mathrm{Hu}$ Jintao went to Shandong, while Wen Jiabao and other central leaders visited Guangdong, Zhejiang, Jiangsu and Shanghai.

9020 million is the figure that was typically reported in the press in early 2009. Discussions in Beijing in March 2009 suggested that the real figure is nearer 25 million out of a total migrant workforce of over 200 million.
} 
- its just that its not as cataclysmic as some of the headline figures pointing to exports accounting for 40 per cent of Chinese GDP might suggest. ${ }^{91}$

It is almost a contractual obligation for a scholar who works on China to point out that the Chinese word for crisis is a combination of two characters - the first, wei 危, meaning 'danger' and the second, $j i$ 机 in this context meaning 'opportunity'. So along with the dangers that the crisis has posed for Chinese growth, it also offers opportunities; for example, the opportunity to push for the long desired increase in domestic consumption as a source of growth and to reduce the reliance on low value added exports. The crisis has also provided an opportunity for China on the international scene - for example, the acknowledgement of China as a key player in the evolution of global economic governance mechanisms and institutions as epitomised by China's role in the G20 London Summit in April 2009.

In terms of China's emerging regional power, it is again too early to know what the long term fall out will be. But building on the analysis that has informed this paper, we can make three tentative suggestions. First, growing support for the need to find alternatives to the 'Washington Consensus' model of international financial governance has important regional implications. The need to seek not just alternative economic modes to 'western' neoliberalism but also regional regulatory alternatives

\footnotetext{
${ }^{91}$ The low level of Chinese components and the low level of value added in these processing exports has long been a source of concern within China - yet ironically this seems to have provided a level of insulation from the vagaries of the global economy in a time of crisis. The decline in exports is still serious and has a significant impact on overall growth figures, but does not cut as deep into the economy as a whole as in some other export oriented economies. I explored the process and implications of this pattern of global integration in Shaun Breslin, China and the Global Political Economy (Basingstoke: Palgrave, 2007).
} 
to global governance appears to have gained support and legitimacy as a result of the current crisis. As Soogil Young argues:

Asia's confidence in the global economic architecture, and by the same token, in its outward-oriented development strategies, has been shaken profoundly ${ }^{92}$ Given the size of its economy and in particular its foreign currency reserves, China will inevitably be a major force in any regional arrangement. To be sure, it may have to share influence with others - notably Japan - but both the ideational appeal and structural power of US finance and models in the region are likely to decline (even if obituaries to US power are a tad premature).

Second, the crisis has allowed China's leaders to reinforce the idea of China as a responsible regional actor. Indeed, China has emerged as almost an über-responsible regional state that is working not just to stabilise its own economy for its own sake, but also to stabilise the regional economy as a whole. Notably, the week after the ASEAN plus Six summit in Thailand was cancelled in the face of widespread political violence in Pattaya, Chinese Premier Wen Jiabao used the 2009 Bo'ao Forum for Asia conference on 'Asia: Managing Beyond Crisis' to promote not just deeper regional cooperation to cope with the crisis, but also the image that China was at the centre of this regional effort.

Which brings us to the third suggestion. The soft 'idea' of China as a leading force for the regional economy in a time of crisis was reinforced by the creation of an altogether more 'hard' source in the form of a US\$10 billion investment fund to support infrastructure projects in ASEAN states to help them cope with the global

\footnotetext{
92 Soogil Young, 'The Case for An East Asian Caucus on Global Governance: A Korean Perspective', East Asia Forum, $12^{\text {th }}$ April 2009 available at http://tinyurl.com/dm8hhm accessed 21st April 2009.
} 
crisis. $^{93}$ In short, in pragmatic material terms, China is becoming increasingly important for the region as a source of finance and, if the Chinese economy recovers as planned, should become an even more significant market in its own right for regional producers (as opposed to an intermediate market for resources used to produce exports to other final markets). If the 1997 crisis marked a key turning point in China's regional economic thinking and policies, so the 2008 global crisis might come to be seen as an event that facilitated a new phase in the consolidation of China's regional role.

\section{Conclusions}

So we can argue about when Chinese policy changed - 1989 for some, the mid 90s, or after 1997. We can also argue about what drives what - international security concerns driving a change in economic strategy to assuage the region, or domestic political/economic perspectives driving a move to engage the region. But there is something of a consensus of what this change has entailed in terms of diplomacy and the proactive promotion of bilateral and multilateral economic cooperation. We should also recognise that growing military capabilities has particular resonance for some regional states - witness, for example, territorial disputes over control of the sea and related resources with Vietnam and Japan.

There is also a consensus that the Chinese authorities have attempted to construct a new national image of China as actor in international relations. But the extent to which regional rise is based on the promotion of a new ideational position rather than 'harder' sources of power and influence is questionable. This is partly because of

\footnotetext{
93 The announcement was planned for the previous week's Asian summit in Thailand and actually first announced by Foreign Minister Yang Jiechi on $12^{\text {th }}$ April before the 'formal' announcement at Bo' ao five days later.
} 
different understandings and definitions of what soft power actually is; indeed, at times, what is 'soft' seems to be anything short of direct political intervention and perhaps military force. The whole point of developing a conception of Soft Power in the first place was to distinguish between different sources of influence. Nye's original understanding might have expanded (or slipped) but including those elements that he originally conceived of as being part of the day to day business of old fashioned 'hard' international relations diminishes the very utility of the concept itself. $^{94}$

So China's regional influence might indeed by predicated on the strategic use of trade and investment strategies (including restricting/offering market access) and promoting diplomatic/economic initiatives at bilateral and multilateral levels. Similarly Lampton is quite right to consider the importance of

being a major recipient of FDI: possessing the world's fastest growing, large domestic market for which the rest of the world is competing; and, the PRCs growing strength as an investor abroad, including holding nearly one trillion US dollars in American debt ${ }^{95}$

But considering these within a very broad definition of soft power makes it difficult to separate out the importance (if any) of culture, values, and norms and attraction to the Chinese 'model' (however defined).

Having said this, the Asian financial crisis of 1997 and the global crisis just over a decade later have both served to undermine confidence in and the legitimacy of what is often perceived to be 'western' globalised capitalism. The search for new regional

\footnotetext{
94 Joseph Nye, Bound to Lead: The Changing Nature of American Power (New York: Basic, 1990).

${ }^{95}$ David Lampton, 'Soft Power, Hard Choices', Chinese Security 4: 3, 2008, p. 8.
} 
forms or regulation and surveillance do not necessarily automatically lead to the adoption of Chinese preferences and the assertion of Chinese supremacy. But when combined with pragmatic Chinese initiatives such as the creation of the ASEAN investment fund, then at the very least, there the chances of undermining the regional influence of the US in the region increase.

Finally, while we can debate whether Ramo's promotion of the idea of a 'Beijing Consensus' helps or hinders an understanding of the dynamics of regional relations, his idea that the sheer size of the country and the economy give it a 'magnetic pull' is illuminating. ${ }^{96}$ Or as Frost put it, 'the sheer size and dynamism of China's economy' is hugely significant in itself and 'may make explicit diplomatic intervention unnecessary' in getting others to acquiesce to Chinese interests. ${ }^{97}$

What this suggests then is that that the Chinese authorities don't really need to do or say very much in a proactive manner to push their influence in the region. Simply dealing with their own domestic economic issues and ensuring continued growth could well be enough in itself. Indeed, a key source of China's 'non-hard' power appears to be the way that some in the region (and beyond) base their relations with China today on the (well founded) expectation of continued growth and on what they expect China to become in the future. So in addition to its own sources of power, perhaps China also possesses a form of 'imagined' power in the minds of others. As such, the way that others in the region conceive of and respond to China's rise might become a source of Chinese power and influence in itself.

\footnotetext{
96 Ramo, The Beijing Consensus.

97 Frost, 'China's Commercial Diplomacy', p. 97.
} 